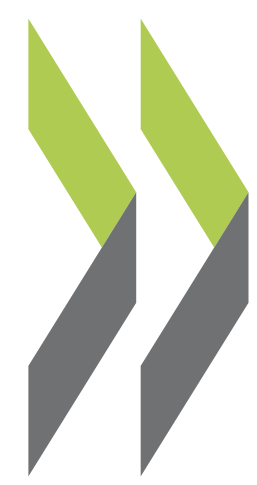

OECD Science, Technology and Industry Working Papers 1998/02

\title{
Information and Communication Technology and the Measurement of Real Output, Final Demand and Productivity
}

\section{Paul Schreyer}


STI WORKING PAPERS

1998/2

INFORMATION AND COMMUNICATION TECHNOLOGY AND THE MEASUREMENT OF REAL OUTPUT, FINAL DEMAND AND PRODUCTIVITY

Paul Schreyer 


\section{STI WORKING PAPER SERIES}

The Working Papers series of the OECD Directorate for Science, Technology and Industry of the OECD is designed to make available to a wider readership selected studies prepared by staff in the Directorate or by outside consultants working on OECD projects. The papers included in the series are of a technical and analytical nature and deal with issues of data, methodology and empirical analysis in the areas of work of DSTI. The Working Papers are generally available only in their original language - English or French - with a summary in the other.

Comment on the papers is invited, and should be sent to Directorate for Science, Technology and Industry, OECD, 2 rue André-Pascal, 75775 Paris Cedex 16, France.

The opinions expressed in these papers are the sole responsibility of the author(s) and do not necessarily reflect those of the OECD or of the governments of its Member countries.

Applications for permission to reproduce or translate all or part of this material should be made to: Head of Publication Service, OECD, 2 rue André-Pascal, 75775 Paris, Cedex 16, France. 


\title{
INFORMATION AND COMMUNICATION TECHNOLOGY AND THE MEASUREMENT OF REAL OUTPUT, FINAL DEMAND AND PRODUCTIVITY
}

\author{
Paul Schreyer*
}

Over the past decades, the majority of information and communication technology (ICT) products have undergone rapid technical change. To the extent that such technical progress benefits consumers and users, quality improvements should be reflected in official price and quantity indices. When this is not the case, there is a tendency to overestimate price movements and underestimate volume changes of ICT products. All statistical offices deal with this issue, but the degree and nature of quality adjustment of price indices of ICT products varies considerably across OECD countries. The present work does not venture to determine "best practice" for quality adjustment in statistical offices. However, it simulates measurement effects on key economic variables (real output, private final consumption, government expenditure, investment, exports and imports), and productivity, under the assumption that the price indices of ICT products are fully quality-adjusted. The paper draws on empirical studies to identify differences between quality-adjusted and unadjusted price changes of several ICT products. These differences are then used to simulate effects on aggregate and industry-level measures of output and productivity for selected OECD countries

* Organisation for Economic Co-operation and Development; Economic Analysis and Statistics Division. This work has been conducted for the OECD Statistical Working Party of the Industry Committee. However, the opinions expressed in the paper are the sole responsibility of the author and do not necessarily reflect those of the OECD or of the governments of its Member countries.

\section{LES TECHNOLOGIES DE L'INFORMATION ET DES COMMUNICATIONS : MESURE DE LA PRODUCTION RÉELLE, DE LA DEMANDE FINALE ET DE LA PRODUCTIVITÉ}

\author{
Paul Schreyer*
}

Au cours de ces dernières décennies, la majorité des produits des technologies de l'information et de la communication (TIC) ont fait l'objet d'une évolution technique rapide. Dans la mesure où ces progrès techniques profitent aux consommateurs et aux utilisateurs, les améliorations apportées à la qualité devraient être prises en compte dans les indices officiels de prix et de quantité. Quand ce n'est pas le cas, on a tendance à surestimer les mouvements de prix et à sous-estimer les variations des volumes des produits liés aux TIC. Tous les services de statistiques font face à ce problème, mais le degré et la nature de l'ajustement des indices de prix des produits des TIC en fonction de la qualité varient considérablement d'un pays à l'autre dans la zone de l'OCDE. La présente étude ne prétend pas mettre en évidence une "pratique exemplaire" d'ajustement en fonction de la qualité dans les services statistiques. Cependant, elle simule les effets des mesures sur des variables économiques clés (production réelle, consommation finale privée, dépenses des administrations publiques, investissements, exportations et importations) ainsi que sur la productivité, en supposant que les indices de prix des produits liés aux TIC sont pleinement ajustés en fonction de la qualité. Cet article s'appuie sur des études empiriques pour mettre en lumière les différences entre variations de prix ajustés et non ajustés en fonction de la qualité, pour plusieurs produits des TIC. Les différences relevées sont alors utilisées pour simuler les effets produits sur les mesures de la production et de la productivité, tant agrégées que sectorielles, pour certains pays de l'OCDE.

* Organisation de coopération et de développement économiques; Division des analyses économiques et des statistiques. Ces travaux ont été menés pour le Groupe de travail statistique du Comité de l'industrie. Les opinions exprimées dans ce document n'engagent que l'auteur et ne reflètent pas nécessairement celles de l'OCDE ou des gouvernements de ses pays Membres. 


\section{Introduction}

Measures of productivity growth are core economic indicators. Because of this importance, there have been extended discussion over two issues related to productivity growth: the widely cited macroeconomic slowdown of productivity growth since the early 1970s; and the so-called "productivity paradox" - the observation that significant investment in information technology has not accelerated productivity growth.

The discussion of both issues has always included mis-measurement as a possible cause: is the productivity slowdown, or the absence of an acceleration of productivity growth from investment in information technology, only a perceived one because measures of output understate true growth? The literature has not come up with a clear-cut answer, not least because the demonstration of measurement error is insufficient - as a slowing of productivity growth or an absence of acceleration have to be explained, it must be shown that measurement errors have actually worsened since the early 1970s and since the rapid investment in information technology.

One of the observations put forward is that investment in information and communication technology has accelerated, triggered by rapidly improving technical performance and improved price-performance ratios. To the extent that such improved performance benefits consumers and users, it should be reflected in official price and quantity indices. When this is not, or only partly, the case, there is a tendency to overestimate price movements and underestimate volume changes of ICT products. If real output of industries or volume GDP was indeed increasingly undermeasured, this could provide an explanation for the productivity slowdown. Hence, the interest in assessing measurement effects of quality adjustment of price series, specifically for ICT products and industries.

More recently, the measurement issue has moved centre-stage in the debate about the accuracy of the consumer price index, triggered by a report by the United States Advisory Commission to Study the Consumer Price Index (Boskin et al., 1996) in late 1996. The report claimed that the United States consumer price index systematically overestimated inflation, thus raising indexed government expenditure and contributing to public deficits. Although views on the size of the bias are far from unanimous, one of the points about which there is little disagreement is that the absence of full quality adjustment for appliances, in particular electronic ones, is a potential source of upward CPI bias. ${ }^{1}$ The conclusion of the present study is that the issue of quality adjustment of prices in the ICT area is widely accepted, even if ideas of how best to deal with it may differ. ${ }^{2}$

Generally, the emergence and diffusion of ICT products have affected economic measurement in two areas:

- First, it is often difficult to accurately measure price indices of ICT products. Because ICT products have undergone rapid technological change, conventional statistical methods to construct price series may inadequately reflect improved quality, performance and greater choice among ICT products. If quality improvements are only partially captured, price indices will tend to overstate inflationary developments and understate quantity changes. Perhaps the best-known

1. As Moulton and Moses (1997) report, the Bureau of Labour Statistics is currently testing new methods of quality adjustment in the CPI.

2. The CPI is not normally used to deflate GDP or output series for productivity measurement, but there are many links between the CPI and national accounts deflators. For example, the CPI is one of the statistical sources to obtain price indices for certain consumer product groups in the national accounts. Any bias in the CPI components could thus carry over to other national accounts. 
example are computers: in the United States, quality-adjusted price indices for computers and peripheral equipment declined at an average rate of over 12 per cent during the 1980s, significantly faster than the conventional measure of price changes. The same reasoning applies to the price and volume measures of other ICT products, for instance semiconductors and communication equipment, as well as certain ICT services such as communication.

- Second, ICT products constitute not only output from one industrial activity, but are also used in other industries. One consequence is that it may have become more difficult to measure inputs, specifically capital inputs, in these ICT-using industries. At the same time, ICT capital goods have often transformed the nature of products: there are many cases where information technology has permitted the creation of entirely new goods and services (for example, telephone banking) or the addition of new varieties to existing products, often facilitating their use or providing customised services. Many of these transformations are found in the service sector, specifically in banking, insurance, retail trade or communication services. This changing nature of goods and services through ICT has amplified existing measurement problems of output in these industries.

This paper focuses on measurement issues. It does so by using national accounts at the industryand economy-wide level and by simulating how quality-adjusted deflators can potentially affect measurement of industry-level and aggregate output, final demand and productivity. Section 2 deals with industry-level productivity measures, and Section 3 turns to different final expenditure components. Section 4 draws some conclusions for the productivity paradox.

\section{Industry productivity measures}

Each of the above measurement issues has consequences for the measurement of productivity, although these will vary between industry-level and aggregate measures of productivity growth just as consequences are different for measures of single factor productivity and multi-factor productivity. This section examines how rapid quality change and new products may bias measures of prices, volumes and productivity in the ICT industries.

To simplify the following discussion, the notion of "quality-adjusted" and "unadjusted" price indices will be used in a somewhat imprecise way: "unadjusted" stands for the traditional treatment of ICT products in price measurement - this may very well comprise some adjustment for quality changes but it is understood to exclude fully fledged methods of quality adjustment such as hedonic models. ${ }^{3}$ Further, "quality adjustment" also subsumes the appropriate treatment of new goods and varieties - an issue closely related to the question of quality change. A more detailed treatment of these statistical issues can be found in Annex 1.

\section{ICT-producing industries}

Office machinery, computer and communication equipment and instruments - the ICT industries in manufacturing - have been steadily growing branches of OECD economies, accounting for 3 to 15 per cent of total manufacturing value added in 1995 (Table 1), depending on the country. The office machinery and computer industry by itself accounts for between 1 and 3 per cent of manufacturing value added, measured at current prices. The radio, TV and communication equipment industry combines a broad spectrum of ICT goods. Hence, individual countries' industries in this group may be of very different composition. ${ }^{4}$ For a

3. See Annex 1.

4. For example, a sizeable part of the Korean industry activity 3832 is in the production of radio, TV and other consumer electronic goods. 
fuller picture of information and communication-producing industries, two service industries must be added to the ICT industries in manufacturing: communication services and computer services. No detailed industry data are available for computer services, but the communication services industry is of significant size: for the OECD area as a whole, it constitutes about the same value added as the ICT-producing manufacturing industries (OECD, 1997a).

Data for the office machinery and computer industry show wide discrepancies in productivity growth rates between countries, largely reflecting the differences in statistical methodologies that underlie the measurement of output price indices (Wyckoff, 1995): rapid measured productivity growth in the United States or Canada as opposed to most European countries is the result of the use of hedonically adjusted price indices in the former countries' national accounts.

Relevant empirical studies (Box 1) show that full quality adjustment of computers and peripheral equipment leads to price indices that fall at least by 10 percentage points more than unadjusted price indices. Table 2 uses this difference to assess how the use of quality-adjusted price indices affects more aggregate measures of labour productivity, in particular in the entire non-electrical machinery industry (the parent sector of the computer industry) and for total manufacturing. Two measures of labour productivity are presented: one, based on a price index for value added that is not, or only partially, adjusted for quality change in computer output; and a second, based on a fully adjusted price index. Note that the figures for the United States and Canada under the "adjusted" column correspond to those actually published, whereas, for other countries, labour productivity growth derived from official data is shown under the "unadjusted" column. Comparison of the unadjusted and adjusted data shows that differences can be substantial, especially as the present calculation (based on a 10 percentage point difference) constitutes a lower bound to such an adjustment. However, several qualifications apply.

First, quality-adjusted price indices for computers are always indices to deflate measures of nominal gross output and their identification with price changes of value added - as in the calculations underlying Table 2 - is a short-cut that may be inappropriate because it does not take into account the price changes of intermediate inputs. A preferred price index for value added is based on the "double-deflation" method, combining deflators of gross output and intermediate inputs. In the present context, this point is of importance as many high-tech industries consume intermediate ICT products whose price changes may in turn be overstated. However, correction for this bias in intermediate goods prices increases the price index of value added (or reduces the volume index of value added) of an industry, because intermediate inputs enter measures of value added with a negative sign. Thus, both output and input prices have to be adjusted to assess the full impact on measured value added and labour productivity. In this sense, the measurement bias may be less than stated in Table 2, although in the case of the United States, it has been shown that the picture does not fundamentally change even if inputs of semiconductors in the computer industry are fully accounted for (Triplett, 1996a).

Second, inter-industry shifts of productivity have to be considered. Whether or not a bias in an industry's output measure carries over to aggregate output measures depends largely on the nature of the industry's output, specifically on the degree to which it is used as an intermediate input in the production of other goods. In the extreme case where an industry produces only for intermediate demand, there will be no effect on real aggregate GDP measures from an adjustment of industry output prices: all effects will be of an inter-industry nature, shifting the growth of real output from the input-consuming industry to the input producing industry. Semiconductors are a case in point: they are largely intermediate goods (except when exported) and a quality adjustment of semiconductor output prices will increase measured productivity in the semiconductor industry but reduce the measured productivity growth in semiconductor-using industries. On the other extreme, adjustment of output prices of an industry that delivers exclusively to final demand will fully carry over to aggregate GDP measures. The full assessment of inter-industry versus aggregate 
effects of measurement biases requires a broad set of information on flows of intermediate inputs between industries which can only be obtained from input-output tables. If only aggregate effects are to be evaluated, a preferred methodology is to examine effects on final demand and its components: private consumption, investment, government expenditure and net exports. This methodology has been pursued in Section 3.

Third, labour productivity is a single factor productivity measure that does not permit to control for substitution effects between labour and other inputs, in particular capital services. A preferred measure is total factor productivity (TFP), a ratio between output and a combined set of inputs: labour, capital and intermediate inputs. ${ }^{5}$ When TFP rather than labour productivity is the measure, a bias in the price index of gross output of ICT-producing industries has several effects. The first one is the understatement of the real gross output growth of the ICT-producing industry. The second effect operates via the mis-measurement of real inputs and is similar to the argument developed with value added: when real measures of intermediate inputs are understated, residual TFP is overstated. The third effect operates via capital input: when the volume of capital input is understated, residual TFP is overstated. Thus, the net effect of introducing quality-adjusted price indices for ICT products on individual industries' TFP measures can in principle be of any sign, depending on the relative strength of the three measurement effects.

\section{ICT-using industries}

The preceding discussion has been conducted with reference to an ICT-producing industry where ICT products with their potential measurement errors enter productivity calculations both on the output and on the input side. However, an important part of the discussion about the economic effects of ICT has been based on the observation that ICT may have generated unmeasured output (Griliches, 1994) in industries that are ICT-users but not ICT-producers. Examples for these sectors are banking, communication and transportation services or health care, where information technology has profoundly altered the nature of services, leading to a much broader variety of products, improved convenience and customer orientation. ${ }^{6}$ Because they are difficult to capture empirically, many improvements and greater choice for customers have not entered price statistics, and welfare improvements from certain ICT-using industries may have gone unnoticed. Although systematic evidence is limited, a number of studies exist, all of which suggest that unmeasured welfare effects may be important. It is apparent that such gains, were they measured, would fully translate into industry productivity measures.

Baily and Gordon (1988) examine deflators used in the United States insurance industry and find that output deflators are driven by the development of input costs: for example, "the auto repair cost index is used for auto insurance, medical costs for medical insurance and so on. [...] Thus, the productivity weakness in the insurance sector is being driven by the escalation of cost indexes in the medical care area" (Baily and Gordon, 1988, p. 395). Bernstein (1997) uses firm-level data for Canadian life insurance companies to construct alternative measures of output and inputs in the industry, and finds that in the second half of the 1980 s total factor productivity growth is about 2 per cent per year - a rate that exceeds TFP growth as traditionally measured.

5. The most common way to calculate TFP changes is to account for each input's contribution to output growth and identify residual, unexplained differences as TFP. Letting $d q$ be the growth rate of volume gross output, $d l, d k$ and $d m$ the growth rates of labour, capital and real intermediate inputs, and $S_{L}, S_{K}$ and $S_{M}$ their respective nominal cost shares, TFP growth is given by $T F P=d q-S_{L} d l-S_{K} d k$.

6. From innovation surveys it emerges that ICTs are key for firm's innovative activities: this is, for example, the case for 84 per cent of German wholesale and retail trade firms or for 96 per cent of all banks (Licht and Moch, 1997). To the extent that innovations are product improvements, this empirical observation is consistent with the hypothesis of unmeasured output or consumer surplus in the services for which ICTs have played an enabling role. 
Fixler and Zieschang (1997) construct new measures for quantity indices of output growth in United States financial services. The authors introduce quality adjustment to capture the effects of improved service characteristics such as volume of transactions per account, automatic teller machines and the number of branches. Certainly the first two elements of quality improvement are directly linked to the use of ICT. Fixler and Zieschang calculate a quality-adjusted quantity index of financial service output that grows by 4.7 per cent per year between 1985 and 1994 - well above the growth of output as traditionally measured.

Only very partial evidence exists from the health industry, another major investor in ICT-based capital goods that have often helped to facilitate or shorten treatment. For example, Roos (1997) illustrates the output measurement of hospital services with the case of eye surgery. Roos describes how hospital output may be underestimated if proxies like the number of treatments or bed-days are employed. In the case of eye surgery, he indicates that true output growth may have been under-measured by 10 percentage points per year between 1980-96.

In sum, the discussion on ICT and the measurement of industry-level productivity shows that:

- The availability of studies and empirical evidence on measurement of volume output is patchy. Most studies have been undertaken for gross output measures of the computer industry, fewer for other ICT-producing manufacturing industries, and fewer still for ICT-using industries in the service sector.

- Independent of the availability of reliable studies on improved measures of ICT-industries' outputs and inputs, the assessment of macroeconomic effects requires detailed knowledge about the flows of intermediate products in the economy. Mis-measurement of output of industries that mainly supply intermediate inputs will affect the composition of measures of real GDP growth but not necessarily the growth rate itself. One way to avoid the extensive data needs that arise from a knowledge of inter-industry product flows is to shift the analysis to the final expenditure part of national accounts.

\section{Aggregate productivity measures}

The following section analyses the impact of the mis-measurement of real output in ICT-producing industries on final demand components and on GDP. Thus, it uses the expenditure component of national accounts as opposed to the production component that was the basis of the industry-level discussion in the preceding section. There are several reasons that favour an expenditure-based approach ${ }^{7}$ for the assessment of aggregate measurement effects:

- Only final goods are present in the expenditure components of GDP, i.e. private consumption, investment, government consumption and net exports. Intermediate products, by definition, constitute input to other industries and do not enter the final demand components. Thus, the cumbersome problem of accounting for inter-industry shifts in measured real output does not arise. ${ }^{8}$

- The simulation of the effects on volume growth measures of different final expenditure components is of interest in itself - they constitute core macroeconomic variables and, as the analysis will show, measurement effects vary significantly between the components of final expenditure.

7. See also Baily and Gordon (1988) and Sichel (1994).

8. Note, however, that the expenditure side of GDP is unsuitable for analysing industry-level productivity measures. Hence, the expenditure-based approach cannot generally replace a production-based approach. 


\section{Introduction of quality-adjusted price indices}

For five countries across the OECD area (the United States, Canada, France, the Netherlands and Japan), information and communication technology products were identified at the finest level of aggregation, for each final demand component and for two points in time - the latest date available and a year around 1985. ${ }^{9}$ Evidence from empirical studies (Box 1 and Box 2) was used to form an estimate about the annual percentage point difference in the price changes of certain ICT products, depending on whether full quality adjustment or not underlies the construction of the price index. For example, one of the assumptions was that a hedonically adjusted price index ${ }^{10}$ for office machinery and computers would rise by at least 10 percentage points per year less than a traditional price index. The next step involved the aggregation over goods and services, with both unadjusted and adjusted price indices. Finally, the impact of introducing fully adjusted price indices for ICT goods on final demand aggregates and on GDP could be evaluated.

Two principles led this simulation: first, it was set up to establish a lower bound for a possible measurement error at the aggregate level. This was obtained by including only goods from ICT-producing industries. No adjustment was made for possible under-measurement of volume output of ICT-using industries such as banking services, although empirical and anecdotal evidence suggests the need for fuller quality adjustment in this industry. Also, the percentage point differences between adjusted and unadjusted price indices were chosen at the lower end of the scale. Second, care was taken to apply sound statistical principles of aggregation across products, through the choice of appropriate index number formulae.

9. Data availability depends on the existence and timeliness of input-output tables as only the latter offer sufficient product-level detail for analysis.

10. See Annex 1 for statistical techniques of quality adjustment. 


\section{Box 1. Computer prices: empirical evidence}

Price and volume measures of mainframe computers, personal computers and peripheral equipment have been the subject of a series of studies. Typically, these studies employ hedonic regression methods (Annex 1) to derive quality-adjusted computer price indices. From the table below it is apparent that: i) fully quality-adjusted computer prices fell at considerably faster rates than indices based on more traditional pricing techniques. For example, Berndt et al. (1995) report an unweighted mean price change of a sample of personal computers of -10.9 per cent per year. Full quality adjustment raises this rate to -31.9 per cent, a 20 percentage-point difference. ii) quality-adjusted price changes vary between products; prices of peripheral equipment (printers, disk drives, etc.) tended to fall less rapidly than those of desktop computers or mainframes. Consequently, price measures at the industry level such as the office machinery and computer industry are likely to be sensitive to the composition of the product mix. However, for most products in the industry, a difference of 10 percentage points between quality-adjusted and unadjusted price indices can be considered a lower bound and in all simulations about the potential impact of the quality adjustment of office machinery and computer industries, this difference has been employed. (Boskin et al. use a 15-percentage point bias to assess the overall effect on the United States consumer price index.)

\begin{tabular}{|c|c|c|c|}
\hline Author & Subject & Period & $\begin{array}{c}\text { Average percentage } \\
\text { change at annual rate } \\
\text { of price change }\end{array}$ \\
\hline \multirow[t]{2}{*}{ Triplett (1989), United States } & \multirow[t]{2}{*}{ Computer "system", hedonic quality adjustment } & $1972-84$ & -16.3 \\
\hline & & $1957-72$ & -23.9 \\
\hline \multirow[t]{2}{*}{ Flamm (1987), United States } & \multirow[t]{2}{*}{ Computer "system", hedonic quality adjustment } & $1972-78$ & -13.7 \\
\hline & & $1957-72$ & -27.9 \\
\hline \multirow[t]{3}{*}{ Cole et. al. (1986), United States } & Disk drives, hedonic quality adjustment & $1972-84$ & -13.4 \\
\hline & Printers, hedonic quality adjustment & $1972-84$ & -14.8 \\
\hline & Displays, hedonic quality adjustment & $1972-84$ & -7.6 \\
\hline Dulberger (1989) & Computers, hedonic quality adjustment & $1972-84$ & -19.4 \\
\hline Gordon (1989), United States & $\begin{array}{l}\text { Mainframes and minicomputers, hedonic quality } \\
\text { adjustment }\end{array}$ & $1972-84$ & -20.0 \\
\hline \multirow[t]{4}{*}{$\begin{array}{l}\text { Berndt et al. (1995), } \\
\text { United States }\end{array}$} & $\begin{array}{l}\text { Personal computers, unadjusted (unweighted mean } \\
\text { price change of models) }\end{array}$ & $1989-92$ & -10.9 \\
\hline & $\begin{array}{l}\text { Personal computers, matched-model (quality } \\
\text { adjusted, but limited to models that existed in } \\
\text { consecutive years) }\end{array}$ & $1989-92$ & -19.3 \\
\hline & Portable computers, hedonic quality adjustment & $1989-92$ & -23.9 \\
\hline & Desktop computers, hedonic quality adjustment & $1989-92$ & -31.9 \\
\hline Oliner (1993), United States & Mainframe computers, hedonic quality adjustment & $1977-84$ & -26.0 \\
\hline $\begin{array}{l}\text { Berndt and Griliches (1993), } \\
\text { United States }\end{array}$ & Microcomputers, hedonic quality adjustment & $1982-88$ & -28.0 \\
\hline Shiratsuka (1995), Japan & Personal computers, hedonic quality adjustment & $1990-94$ & $-20.0---25.0$ \\
\hline \multirow[t]{5}{*}{ Sadée (1996), United States } & Mainframe computers, hedonic quality adjustment & $1985-94$ & -10.5 \\
\hline & Personal computers, hedonic quality adjustment & $1985-94$ & -19.4 \\
\hline & Disk drives, hedonic quality adjustment & $1985-94$ & -4.6 \\
\hline & $\begin{array}{l}\text { Printers and other peripherals, hedonic quality } \\
\text { adjustment }\end{array}$ & $1985-94$ & -16.9 \\
\hline & Terminals, hedonic quality adjustment & $1985-94$ & -20.4 \\
\hline INSEE (1997), France & Microcomputers, hedonic quality adjustment & $1988-96$ & -32.5 \\
\hline Baldwin et al. (1997), Japan & $\begin{array}{l}\text { General purpose and personal computers, } \\
\text { matched-model }\end{array}$ & $1985-92$ & -9.0 \\
\hline
\end{tabular}




\section{Box 2. Prices of other ICT products: empirical evidence}

Radio, TV, appliances and communication equipment constitute another import ICT product group, including items such as telephones, fax machines, radio and TV sets and VCRs. For appliances and radio-TV, Gordon (1990) reports an estimated upwards price bias of just above 3 percentage points for appliances and close to 6 percentage points for radio-TV. Boskin et al. (1996) estimate the overall bias at 3 per cent for appliances, 4 per cent for radio-TV including VCRs. For the purpose of the present report, and where these products can be distinguished, a 2-percentage point bias is assumed as a lower bound. No comprehensive studies exist on quality change in communication equipment goods but the appearance of many new features in telephone equipment, the emergence of cellular phones, improvements in the quality and convenience of fax machines would seem to justify a similar difference of 2 percentage points between adjusted and unadjusted rates of price change.

Semiconductors are the ICT products that have probably experienced the most rapid decline in quality-adjusted prices. Triplett (1996) reports on world-wide semiconductor price indices, produced by Grimm (1995) for seven different types of memory chips and two types of microprocessor chips. Between 1985 and 1994, semiconductor prices fell at rates of 31 per cent per year (microprocessor chips), 19.7 per cent (memory chips) and 24.7 per cent (semiconductors). Where product-level data are available, this compares with unadjusted price indices that fall by 7.2 per cent (Japan) and 1 per cent (Netherlands - although this relates to a somewhat broader product category). Again, 10 percentage points are adopted as a lower bound for the possible bias due to absence of quality adjustment or to sampling methods that understate true price changes.

\begin{tabular}{llll}
\hline \multicolumn{1}{c}{ Author } & \multicolumn{1}{c}{ Subject } & Period & $\begin{array}{c}\text { Average percentage } \\
\text { change at annual rate }\end{array}$ \\
\hline Grimm (1995) & Semiconductors, hedonic quality adjustment & $1974-94$ & -39.9 \\
& & $1985-94$ & -24.7 \\
\hline Norsworthy and Jang (1993) & $\begin{array}{l}\text { Semiconductors, used in computer industry, } \\
\text { hedonic quality adjustment }\end{array}$ & $1969-86$ & -20.7 \\
\hline Dulberger (1993) & Metal oxygen on silicon memory chips, hedonic & $1977-88$ & $\begin{array}{c}\text { Between }-26.5 \% \text { and } \\
-38.0 \% \text {, depending on } \\
\text { index number formula }\end{array}$ \\
\hline
\end{tabular}

Scientific and measurement instruments are another category of ICT products. Developments in ICT have significantly influenced scientific instruments and the way these are used by scientists. The kind of computer-based tools that are used vary by discipline. In some disciplines, greater computing power has allowed better visualisation of results, and has significantly improved modelling, simulation and computational analysis. In other disciplines, scientific instruments have been revolutionised by miniaturisation, or by the development of virtual instruments. This has significantly lowered the costs of some instruments and has also made scientific instruments more flexible (OECD, forthcoming). There are few systematic studies of quality-adjusted price measures. Among those carried out, Trajtenberg's (1990) work on CT scanners has shown the most striking results: while the unadjusted price index for scanners rises by about 50 per cent over 5 years and hedonic methods show a decline of 30 per cent, Trajtenberg's technique that aims at capturing the full welfare effects of innovation, marks a 50 per cent fall of the price index. The picture becomes even more pronounced when earlier years are taken into account. Although CT scanners may not be representative for the entire product group "instruments", they certainly confirm more anecdotal evidence on the advancement of performance of instruments in the medical area, such as laser-based operating equipment or ICT-based devices for micro-surgery. 


\section{Box 3. Prices of other ICT products: empirical evidence}

Computer and communication services. Empirical studies on price indices of computer services are scarce. However, there is some evidence on the price development in the software industry. A study by Gandal (1994) on hedonically adjusted price indices of spreadsheets in the United States produces a yearly average decline of 15 per cent. Harhoff and Moch (1996) construct hedonic and matched-model indices for PC database software in Germany. Their results show a 7.4 per cent decline between 1986 and 1994. Harhoff and Moch explain the difference in price declines by differences in market structures, by the fact that Gandal's study relates to spreadsheets and theirs to database software and by the observation that their prices are transaction prices while Gandal's observations are based on list prices: "In Germany and the United States, software producers were forced to bring down list prices because list prices were about two to three times higher than the respective 'street' prices" (Harhoff and Moch, 1996, p. 17). This would explain a sharper decline in list prices than in street prices. Other evidence on software prices was produced by Oliner and Sichel (1994) who constructed a matched-model index for PC application software between 1985 and 1993. The price decline that they note is much smaller than Gandal's - on average just less than 3 per cent per year. Finally, Statistics Canada employ a software price index in the construction of Canadian SNA input-output tables that declines by 6 per cent per year. This estimate was constructed by observing the trend of software prices over time for popular PC software. While not a fully fledged hedonic measure, it observes the same rules and the results are in line with other studies. For the simulations in this paper, a 2-percentage point difference has been chosen to reflect the deviance of fully (hedonically) adjusted price indices for software from partial or unadjusted price indices.

\begin{tabular}{lllc}
\hline \multicolumn{1}{c}{ Author } & \multicolumn{1}{c}{ Subject } & Period & $\begin{array}{c}\text { Average percentage } \\
\text { change at annual rate }\end{array}$ \\
\hline $\begin{array}{l}\text { Gandal (1994), } \\
\text { United States }\end{array}$ & Spreadsheets, list prices, hedonic quality adjustment & & $-15.0 \%$ \\
\hline $\begin{array}{l}\text { Oliner and Sichel (1994), } \\
\text { United States }\end{array}$ & Word processors, matched-model index & $1985-93$ & $-2.6 \%$ \\
& Spreadsheets, matched-model index & $1987-93$ & $-1.1 \%$ \\
& Databases, matched-model index & $1985-93$ & $-4.5 \%$ \\
\hline $\begin{array}{l}\text { Harhoff and Moch (1996), } \\
\text { Germany }\end{array}$ & Databases, "street" prices, hedonic quality adjustment & $1985-93$ & $-4.7 \%$ \\
\hline
\end{tabular}

\section{Fixed-weight and "superlative" index numbers}

One of the effects of introducing fully quality-adjusted prices for certain goods is that relative prices between the latter and other products change unusually fast. As a consequence, the base-year weights that are typically used to form aggregate price or volume indices across products may quickly become obsolete because buyers react to changes in relative prices and substitute away from those goods and services whose relative prices rise towards those goods and services whose relative prices fall. When weights remain unchanged, for example in a price index for a fixed basket of consumption goods, there is a tendency to give too much weight to the prices that rise rapidly and too little weight to those prices that fall over a given period. In quantity indices with (price) weights fixed in a base year, too much importance is given to those products whose quantities increase fast and whose relative prices fall and too little importance to those products whose prices increase and that were decreasingly demanded. Thus, price indices with fixed base-year weights will tend to overstate aggregate price changes and quantity indices with fixed base-year weights will tend to overstate aggregate quantity changes. ${ }^{11}$

11. It is assumed that the base year precedes the year under consideration. 
In the case of ICT products whose relative prices have declined fast, the implication is that quantity indices with fixed base-year weights are biased upwards, i.e. the effects of fast-declining ICT prices will be overestimated. This upward bias will increase as one moves away from the fixed base year because weights are increasingly out of date. To eliminate this bias, other index number formulae have to be chosen that better reflect the changing weights of ICT goods. ${ }^{12}$ It has been shown that this is best accomplished by "superlative" index numbers, such as the Fisher Ideal index or the Törnqvist index. In practice, annually weighted Laspeyres quantity indices also provide a good approximation to the theoretically preferable superlative indices. In the present simulation, switches between index number formulae were explicitly taken into account to isolate two separate effects:

- A quality adjustment effect, showing by how much volume GDP growth and its final demand components would rise if prices of ICT goods were fully adjusted for quality improvements. This quality adjustment effect was, however, calculated using a fixed-weight index number formula and therefore tends to overstate the final effect.

- An index number effect, showing by how much volume GDP growth and that of its final demand components would fall if, under fully quality adjusted prices, fixed-weight indices were replaced by Fisher Ideal indices. ${ }^{13}$

\section{Results}

An important determinant of the impact of a price-adjustment of ICT goods in final expenditure components is the share that ICT products occupy in these components. In the five countries examined, and for the entire final expenditure aggregate, these shares vary between 2 and 8 per cent (Table 3), depending on the country. Because these shares are measured in current prices, rapid quantity changes are offset by price declines and the overall final demand shares have remained stable or even declined. However, there is great variation between the different final demand components: ICT products account for substantially larger and, often, rising shares of gross fixed capital formation, exports and imports. ${ }^{14}$

Caution is necessary when these shares are compared across countries. Calculations are based on national input-output tables that provide useful detail (Table 6) but with significant differences in product definitions. As a consequence, the exact list of products included in the ICT category (Table 7) varies between countries, introducing an aggregation bias whose magnitude is difficult to determine. Also, the national data from the Netherlands are based on annually-weighted index number formulae and so that fixed-weight indices had to be specifically constructed (see Table 6).

As a point of illustration, Table 4 shows the same shares as Table 3, but measured at constant, base-year prices. These real shares rise strongly for most final expenditure components and all five countries. Note, however, that the size of real shares, based on fixed-weight indices, varies strongly with the choice of the base year. Indeed, nearly any share could be obtained by appropriate choice of the base year.

12. To accommodate for such biases, several national statistical offices (such as Canada and the United States) have introduced alternative price and quantity index number formulae in their national accounts. For a full discussion, see Young (1992); Triplett (1992); Landefeld and Parker (1995).

13. See Annex 2 for methodological details.

14. For reasons evoked above, ICT final expenditure shares are not necessarily of the same magnitude as value-added shares of ICT industries: they follow different principles of aggregation (products $v s$. activities) and correspond to different sides of the national accounts (production vs. expenditure). 
Table 5 is the reference for the discussion of the simulated measurement effects on the different final expenditure components. It lists, for each of the five countries, real growth rates for each component of final expenditure. ${ }^{15}$

- In line A, these growth rates are based on original national data. As such, they reflect full quality adjustment for certain products, for example computers in the case of the United States, Canada or France, and no quality adjustment for others.

- In line B, growth rates are simulated in a situation without quality adjustment. In the case of Japan and the Netherlands, this coincides with the original data because no specific (hedonic) quality adjustment is present for any ICT product. In the case of France, the United States and the United Kingdom, the hedonic quality adjustment for computers was removed.

- In line $\mathrm{C}$, growth rates are simulated in a situation with full quality adjustment. ICT price changes were modified in line with the assumptions specified in Boxes 1 to 3. Lines A, B and C were all evaluated using indices with fixed base-year weights.

- In line $\mathrm{D}$, the index number formula is changed and growth rates are simulated with a Fisher-type index that combines weights from the base year and the final year. As in line $\mathrm{C}$, full quality adjustment is assumed.

- Consequently, the pure quality adjustment effect can be evaluated as the difference between lines $\mathrm{B}$ and $\mathrm{C}$, and the index number effect as the difference between lines $\mathrm{C}$ and $\mathrm{D}$. A positive sign of these effects indicates an understatement of volume growth of the expenditure component, a negative sign an overstatement.

\section{Personal and government expenditure}

The volume growth rates of the personal and government expenditure components of final demand hardly change if fully quality-adjusted price measures for ICT products replace unadjusted ones. This modest effect reflects the comparatively small share of ICT products in private consumption expenditure as well as the specific treatment of government expenditure on ICT products in several countries (Table 6). However, it should also be noted that, with the exception of France, the observation period ends in the early or mid-1990s. Meanwhile, the equipment of private households with personal computers has been progressing further, partly in parallel with the occurrence and spread of the Internet and government communication infrastructure initiatives (OECD, 1997a). Still, the overall conclusion remains, that compared to other final demand components, personal and government expenditure are least sensitive to measurement biases in ICT products. ${ }^{16}$

\section{Investment}

The investment (more precisely, gross fixed capital expenditure) component of final demand registers an important potential impact from ICT mis-measurement. At annual rates, the introduction of quality adjustment raises measured volume investment growth by between 0.8 and 1.5 percentage points $-\mathrm{a}$

15. See Annex 2 for methodological details.

16. In the discussion about the consumer price index in the United States, the Advisory Commission to Study the Consumer Price Index estimated the quality change and new product bias associated with radio-TV, VCRs, and personal computers at 0.1 percentage points per year to the total consumer price index. 
sizeable amount that is an immediate consequence of the importance of ICT capital goods in overall investment. Similar sensitivity has been reported by McCarthy (1997) who examined the effects on aggregate measures of investment of introducing a hedonically adjusted price index for computers into the Australian national accounts.

The investment component is also a telling case for the importance of the index number effect that considerably attenuates the quality-adjustment effect: in the case of the Netherlands, for example, where the quality-adjustment effect shows a measurement difference of 1.4 percentage points, the index number effect reduces this difference by half and leaves a net effect of 0.7 percentage points.

Apart from the obvious interest in correctly measuring real investment outlays, there is a possible implication for the measurement of the economy's capital stock ${ }^{17}$ and further, its total factor productivity measures. Data on real investment flows enters the computation of capital stocks and a change in the deflation of ICT capital goods with an associated rise of aggregate investment will also lead to a rise in the measured capital stock. As Hulten (1992) has shown for the United States, the failure of adjusting capital for quality change has the effect of suppressing the quality effects into the conventional total factor productivity residual instead of associating them with the capital stock. In other words, in the absence of quality adjustment of capital goods deflators, a part of overall technical change is wrongly allocated to and interpreted as disembodied technical change where in fact it is embodied in capital goods. This distinction does not change the overall rate of technical change but its nature as disembodied or embodied in capital goods.

\section{Net exports}

The foreign trade component of final expenditure, exports and imports, shows the largest potential measurement impact from the quality adjustment of ICT products. The quality-adjustment effect for export measures ranges from 0.6 percentage points per year in France to 2.5 percentage points in Japan. Effects on volume import measures are also sizeable, with nearly 1.5 percentage points in the United States, Canada and the Netherlands. As before, the shift to Fisher-type superlative index number formulae provides a counter-balance but net effects remain clearly visible.

\section{Overall final expenditure}

This leads into the discussion of the measurement effects on overall final expenditure. On a net basis, i.e. after factoring in the index number changes, only the simulations for Japan show a 0.4-percentage point effect, implying that if it moved from a situation without quality adjustment to one with full adjustment accompanied by a modification of index number formulae, this would have translated (for the 1985-93 period under consideration) into an increase in measured growth of 0.4 percentage points. ${ }^{18}$ Clearly, this result is driven by the relative importance of ICT products in Japanese investment expenditure and, more importantly, by the relative importance of exports in Japanese total final expenditure. In the other four countries, net aggregate effects are zero or of an order of magnitude that lies within the computational error margin of national accounts.

17. The quality adjustment of computers has also revived and advanced a more general debate about the measurement of the capital stock, notably the choice of the appropriate deflator for investment goods that enter capital stock calculations [for example, Denison (1989) and the measurement issues involved in the use of capital stock data for the analysis of production and productivity (Triplett, 1996a)].

18. The present calculation is based on total final expenditure, and varies from GDP by the omission of the "changes in stocks" component of final demand whose influence is, however, small. 


\section{Implications for the "productivity paradox"}

The well-known "productivity paradox" relates to the observation that despite heavy investment in ICT capital goods, productivity growth in most OECD economies has not accelerated in consequence. Mis-measurement has been one of the explanations put forward to resolve the paradox. It has already been noted that a measurement explanation of the productivity paradox requires that mis-measurement increases over time. The mere statement of mis-measurement of productivity growth over a given period is not enough to explain a slowdown or absence of acceleration. At the level of the aggregate economy, at least one of two conditions must hold to make a case for the measurement explanation: $i$ ) a rising measurement bias for individual sectors or products; and/or ii) a rising share of these sectors or products in aggregate output or productivity. In light of the earlier discussion of the various effects of ICT measurement on productivity, some conclusions can be drawn for the productivity paradox.

First, there is clearly an issue concerning the measurement of real output of ICT-producing industries. Where quality-adjusted output measures have been introduced, this has led to an acceleration of measured productivity growth that even fed through to sectoral aggregates such as total manufacturing. Note also from Table 1 that the share of ICT-producing industries has generally increased. Thus, if the output of ICT-producing industries is not quality adjusted, their rising share may contribute to a possible measurement bias at the aggregate level.

Second, there are reasons to believe that some gross output growth of ICT-using industries, mainly in the service sector, may have gone unnoticed: customer orientation, 24-hour service in banking, retail convenience, improved quality of medical treatment, the increased choice of products and their reliability and quality are all dependent on the intensive use of ICT but hard to capture by traditional output statistics. If the share of unmeasured output has increased, which is possible given the rising share of ICT in these industries' total investment, this would also contribute to the case for a measurement explanation of the productivity paradox. Unfortunately, the very measurement difficulties have also left big gaps in empirical research evidence that would be necessary to assess the extent of unmeasured output.

Note that in major ICT-using industries there is also an input-related measurement effect: the rate and intensity at which these industries have invested in ICTs has risen over the past decade (OECD, 1997b). If ICT capital goods are under-measured (because their quality improvement is insufficiently reflected), the contribution of ICT capital goods to output growth is understated. It follows that there is a bias in the interpretation of technical change in ICT-using sectors: insufficient weight is given to technical improvements embodied in capital goods and too much weight to disembodied technical change. This sheds light on the productivity paradox in that it shows that ICT capital goods have increased their contribution to output (and labour productivity) growth (Stiroh, 1997). It cannot, however, shed light on the slowing of output or productivity growth as such.

Third, in other industries that are neither ICT producers nor intensive ICT users, the share of ICT capital goods in overall productive capital may simply be too small to expect sizeable effects on output growth [an argument that Oliner and Sichel (1994) develop at the level of the aggregate economy]. Only to the extent that a supra-normal return to ICT on productive efficiency is expected does a productivity paradox prevail in these industries.

Fourth, at the level of the entire economy, it emerged that the share of ICT products in total final expenditure is comparatively small and hardly increased over the period under consideration (Table 3). As a consequence, the simulated measurement errors (Table 5) of total final expenditure are small. Even if the mis-measurement of individual ICT products increased (which was not investigated in Section 2), the aggregate effect would most probably have been small. 
In sum, the measurement issue does shed some light on the productivity paradox, although a differentiated view is required: ICT-producing industries have to be distinguished from ICT-using ones and the industry-level from the aggregate economy. Mis-measurement remains a valid explanation for unmeasured productivity growth in ICT-producing industries. Also, in some ICT-using industries, new goods and services and consumer benefits enabled by ICT may have gone unnoticed. In addition, because ICT capital goods have replaced other factors of production, measurement errors in ICT prices would change the interpretation of technical change. At the aggregate level, measurement effects at the industry level partly net out and ICT goods and services remain a comparatively stable part of total final demand. Thus, at the level of economy-wide GDP, it is more difficult to make a case for mis-measurement as an explanation behind sluggish productivity growth than at the level of specific industries.

Table 1. Share of ICT-producing industries in manufacturing value added

Current prices, percentages

\begin{tabular}{|c|c|c|c|c|c|c|c|c|}
\hline & \multicolumn{2}{|c|}{$\begin{array}{c}\text { Office and computing } \\
\text { machinery } \\
\text { (ISIC Rev.2 3825) }\end{array}$} & \multicolumn{2}{|c|}{$\begin{array}{c}\text { Radio, TV and } \\
\text { communication } \\
\text { equipment } \\
\text { (ISIC Rev.2 3832) }\end{array}$} & \multicolumn{2}{|c|}{$\begin{array}{c}\text { Scientific and } \\
\text { professional } \\
\text { instruments } \\
\text { (ISIC Rev. } 2 \text { 3850) }\end{array}$} & \multicolumn{2}{|c|}{ Total } \\
\hline & 1980 & 1995 & 1980 & 1995 & 1980 & 1995 & 1980 & 1995 \\
\hline Australia $^{1}$ & 2.3 & 1.9 & 0.3 & 0.2 & 1.0 & 0.9 & 3.5 & 3.0 \\
\hline Austria & . & . & $\ldots$ & . & 0.8 & 0.8 & & \\
\hline Belgium & $\ldots$ & $\ldots$ & . & $\ldots$ & 0.6 & 1.1 & & \\
\hline Canada & 0.7 & 0.9 & 2.8 & 4.0 & 1.5 & 1.6 & 5.1 & 6.5 \\
\hline Denmark & 0.5 & 0.8 & 2.4 & 2.2 & 2.1 & 2.1 & 5.0 & 5.1 \\
\hline Finland & 0.5 & 1.0 & 1.2 & 5.7 & 0.8 & 1.9 & 2.4 & 8.7 \\
\hline France & 1.6 & 2.0 & 4.0 & 4.8 & 1.4 & 1.6 & 7.0 & 8.4 \\
\hline Greece & 0.0 & 0.0 & 0.7 & 1.2 & 0.1 & 0.1 & 0.8 & 1.4 \\
\hline Italy & 0.9 & 0.9 & 2.0 & 2.3 & 2.3 & 2.2 & 5.2 & 5.4 \\
\hline Japan & 1.7 & 2.8 & 5.6 & 8.7 & 2,0 & 1.6 & 9.3 & 13.0 \\
\hline Korea $^{1}$ & 0.1 & 1.0 & 6.5 & 12.7 & 1.2 & 1.4 & 7.8 & 15.0 \\
\hline Mexico & 0.5 & 1.7 & 3.0 & 2.6 & 0.5 & 0.9 & 4.0 & 5.3 \\
\hline Netherlands ${ }^{2}$ & 0.8 & 0.6 & 10.9 & 9.4 & 1.3 & 1.6 & 13.1 & 11.6 \\
\hline New Zealand ${ }^{2}$ & 0.1 & 0.3 & 1.0 & 0.9 & 0.3 & 0.4 & 1.5 & 1.5 \\
\hline Norway & 0.6 & 0.2 & 2.5 & 2.5 & 0.4 & 0.8 & 3.5 & 3.5 \\
\hline Portugal $^{1}$ & 0.2 & 0.1 & 2.4 & 2.9 & 0.3 & 0.7 & 2.9 & 3.6 \\
\hline Spain & 0.2 & 0.5 & 2.2 & 2.0 & 0.4 & 0.3 & 2.8 & 2.8 \\
\hline Sweden & 1.1 & 0.5 & 4.3 & 4.1 & 1.2 & 3.2 & 6.6 & 7.7 \\
\hline United Kingdom & 1.2 & 2.0 & 4.4 & 4.6 & 1.3 & 1.5 & 7.0 & 8.1 \\
\hline United States & 2.0 & 1.7 & 3.4 & 7.6 & 4.5 & 4.5 & 10.0 & 13.8 \\
\hline Western Germany & 1.3 & 1.7 & 5.3 & 6.3 & 2.8 & 2.7 & 9.4 & 10.7 \\
\hline G7 & 1.6 & 1.9 & 4.0 & 6.8 & 3.0 & 3.0 & 8.7 & 11.6 \\
\hline
\end{tabular}

1. 1994.

2. 1993.

Source: OECD, STAN database. 
Table 2. Effect of a 10-percentage point adjustment of prices in the computer industry 1984-95, average percentage change at annual rate

\begin{tabular}{|c|c|c|c|c|c|c|}
\hline & \multicolumn{6}{|c|}{ Non-electrical machinery industry (ISIC 382) } \\
\hline & $\begin{array}{l}\text { Current price } \\
\text { value added }\end{array}$ & $\begin{array}{c}\text { Value added } \\
\text { deflator } \\
\text { unadjusted }\end{array}$ & $\begin{array}{l}\text { Value added } \\
\text { deflator } \\
\text { adjusted }^{1}\end{array}$ & Employment & $\begin{array}{l}\text { Productivity } \\
\text { unadjusted }^{3}\end{array}$ & $\begin{array}{l}\text { Productivity } \\
\text { adjusted }^{3}\end{array}$ \\
\hline & $A$ & $B$ & $\mathrm{C}$ & $\mathrm{D}$ & A-B-D & A-C-D \\
\hline United States $^{1}$ & 2.8 & 0.1 & -1.8 & -1.3 & 4.0 & 5.9 \\
\hline Japan & 1.3 & 0.8 & -1.6 & 0.6 & -0.1 & 2.3 \\
\hline Germany & 2.0 & 2.4 & 0.8 & -0.3 & -0.1 & 1.6 \\
\hline France & 0.4 & 0.0 & -2.7 & -2.0 & 2.4 & 5.0 \\
\hline United Kingdom & 4.0 & 2.9 & 1.3 & -0.4 & 1.5 & 3.1 \\
\hline Italy & 5.3 & 5.0 & 3.8 & -1.5 & 1.8 & 3.0 \\
\hline \multirow[t]{2}{*}{ Canada ${ }^{2}$} & 5.3 & 0.6 & -0.7 & 1.4 & 3.3 & 4.7 \\
\hline & \multicolumn{6}{|c|}{ Total manufacturing (ISIC 3000) } \\
\hline United States $^{2}$ & 4.4 & 2.7 & 2.4 & -0.4 & 2.2 & 2.4 \\
\hline Japan & 2.4 & -0.1 & -0.4 & 0.5 & 2.0 & 2.3 \\
\hline Germany & 3.1 & 2.4 & 2.2 & -0.7 & 1.4 & 1.6 \\
\hline France & 3.6 & 2.5 & 2.3 & -1.8 & 2.8 & 3.0 \\
\hline United Kingdom & 5.1 & 3.3 & 3.1 & -1.0 & 2.8 & 3.0 \\
\hline Italy & 5.7 & 3.8 & 3.7 & -1.2 & 3.0 & 3.2 \\
\hline Canada $^{2}$ & 4.4 & 3.1 & 3.0 & -0.6 & 2.0 & 2.1 \\
\hline
\end{tabular}

1. The adjusted price change for value added in the non-electrical machinery industry 382 has been calculated as $\mathrm{Pa}(382)=\mathrm{Pu}(382)-\mathrm{s}^{*}(\mathrm{Pu}(3825)-\mathrm{Pa}(3825))$, where $\mathrm{Pa}(382)$ is the adjusted price change of value added in industry $382 ; \mathrm{Pu}(382)$ is the unadjusted price change of value added in industry $382 ; \mathrm{s}$ is the current price share of the computer industry 3825 in industry 382 and $\mathrm{Pu}(3825)-\mathrm{Pa}(3825)=0.1$ is the 10-percentage point difference between unadusted and adjusted deflators for value added of the computer industry.

2. As both the United States and Canada use quality-adjusted (hedonic) price indices in their output price measures of the computer industry (3825), the figures presented under "adjusted" correspond to the original and published productivity measures. For all other countries, the reverse holds.

3. As explained in the text, this methodology presents only an approximation to the true effects on value-added measures and productivity.

Source: OECD, based on STAN database. 
Table 3. Share of ICT products in total final expenditure components Current prices, percentages

\begin{tabular}{lccccrrr}
\hline & & $\begin{array}{c}\text { Private } \\
\text { consumption }\end{array}$ & $\begin{array}{c}\text { Government } \\
\text { expenditure }\end{array}$ & $\begin{array}{c}\text { Gross fixed } \\
\text { capital } \\
\text { formation }\end{array}$ & Exports & Imports & $\begin{array}{c}\text { Final } \\
\text { expenditure }\end{array}$ \\
\cline { 2 - 9 } & 1986 & 2.4 & 2.3 & 4.7 & 4.2 & 7.4 & 1.9 \\
France & 1992 & 2.2 & 2.2 & 7.4 & 6.3 & 10.4 & 1.8 \\
\hline Japan & 1985 & 3.3 & $\ldots$ & 10.1 & 6.9 & 8.6 & 3.5 \\
Netherlands & 1996 & 2.9 & $\ldots$ & 9.6 & 9.2 & 11.5 & 3.1 \\
\hline United States & 1985 & 3.7 & $\ldots$ & 10.3 & 22.4 & 3.7 & 7.8 \\
& 1994 & 3.5 & $\ldots$ & 8.1 & 23.2 & 8.5 & 5.9 \\
\hline
\end{tabular}

Source: OECD, based on national input-output tables.

Table 4. Share of ICT products in total final expenditure components ${ }^{1}$

Base-year prices, percentages

\begin{tabular}{|c|c|c|c|c|c|c|c|}
\hline & & $\begin{array}{c}\text { Private } \\
\text { consumption }\end{array}$ & $\begin{array}{l}\text { Government } \\
\text { expenditure }\end{array}$ & $\begin{array}{c}\text { Gross fixed } \\
\text { capital } \\
\text { formation }\end{array}$ & Exports & Imports & $\begin{array}{c}\text { Final } \\
\text { expenditure }\end{array}$ \\
\hline \multirow[t]{2}{*}{ Canada } & 1986 & 2.4 & 2.3 & 4.7 & 4.2 & 7.4 & 1.9 \\
\hline & 1992 & 3.2 & 3.4 & 13.5 & 9.5 & 16.7 & 2.5 \\
\hline \multirow[t]{2}{*}{ France } & 1985 & 3.3 & $\cdots$ & 10.1 & 6.9 & 8.6 & 3.5 \\
\hline & 1996 & 4.7 & . & 15.6 & 10.6 & 12.8 & 5.1 \\
\hline \multirow[t]{2}{*}{ Japan } & 1985 & 3.7 & . & 10.3 & 22.4 & 3.7 & 7.8 \\
\hline & 1994 & 5.1 & . & 17.0 & 35.1 & 10.2 & 11.4 \\
\hline \multirow[t]{2}{*}{ Netherlands } & 1986 & 1.2 & $\ldots$ & 8.8 & 6.8 & 8.8 & 2.1 \\
\hline & 1993 & 1.8 & . & 13.2 & 9.5 & 13.1 & 2.8 \\
\hline \multirow[t]{2}{*}{ United States } & 1987 & 2.5 & 4.5 & 10.1 & 11.1 & 10.5 & 3.9 \\
\hline & 1993 & 3.6 & 4.3 & 19.4 & 17.3 & 21.0 & 5.4 \\
\hline
\end{tabular}

1. Constant-price shares are based on fixed-weight indices and can vary strongly with the choice of the base year. Indeed, nearly any share could be obtained by appropriate choice of the base year. Consequently, the present table should be interpreted with the necessary caution.

Source: OECD, based on national input-output tables. 
Table 5. Quality adjustment of final expenditure measures: simulation results

Volume growth, average percentage change at annual rate

\begin{tabular}{|c|c|c|c|c|c|c|c|}
\hline & & $\begin{array}{c}\text { Private } \\
\text { consumption } \\
\text { expenditure }\end{array}$ & $\begin{array}{l}\text { Government } \\
\text { expenditure }\end{array}$ & Investment & Exports & Imports & $\begin{array}{l}\text { Total final } \\
\text { expenditure }\end{array}$ \\
\hline \multicolumn{8}{|l|}{ Canada, 1986-92 - based on: } \\
\hline $\begin{array}{l}\text { Fixed-weight (Laspeyres) volume } \\
\text { index, original data } 1\end{array}$ & & 2.15 & 2.81 & 3.42 & 5.32 & 6.09 & 2.22 \\
\hline $\begin{array}{l}\text { Fixed-weight (Laspeyres) volume } \\
\text { index, no quality adjustment }{ }^{2} \\
\text { Fixed-weight (Laspeyres) volume }\end{array}$ & A & 2.12 & 2.74 & 2.64 & 4.94 & 5.30 & 2.18 \\
\hline $\begin{array}{l}\text { index, full quality adjustment } \\
\text { Superlative (Fisher) volume }\end{array}$ & B & 2.21 & 2.85 & 3.49 & 5.66 & 6.57 & 2.21 \\
\hline index, full quality adjustment ${ }^{4}$ & C & 2.13 & 2.73 & 3.05 & 5.22 & 5.95 & 2.15 \\
\hline $\begin{array}{l}\text { Quality-adjustment effect under } \\
\text { fixed weights }{ }^{5} \\
\text { Index number effect }^{5}\end{array}$ & $\begin{array}{l}B-A \\
C-B\end{array}$ & $\begin{array}{r}0.09 \\
-0.08\end{array}$ & $\begin{array}{r}0.10 \\
-0.12\end{array}$ & $\begin{array}{r}0.85 \\
-0.44\end{array}$ & $\begin{array}{r}0.73 \\
-0.45\end{array}$ & $\begin{array}{r}1.28 \\
-0.62\end{array}$ & $\begin{array}{r}0.03 \\
-0.06\end{array}$ \\
\hline Total effect $^{5}$ & C-A & 0.02 & -0.01 & 0.41 & 0.28 & 0.66 & -0.03 \\
\hline \multicolumn{8}{|l|}{ France, $1985-96$ - based on: } \\
\hline $\begin{array}{l}\text { Fixed-weight (Laspeyres) volume } \\
\text { index, original data } 1\end{array}$ & & 2.15 & 2.04 & 2.07 & 4.50 & 4.58 & 2.09 \\
\hline $\begin{array}{l}\text { Fixed-weight (Laspeyres) volume } \\
\text { index, no quality adjustment }{ }^{2} \\
\text { Fixed-weight (Laspeyres) volume }\end{array}$ & A & 2.14 & 2.04 & 1.53 & 4.28 & 4.28 & 2.01 \\
\hline $\begin{array}{l}\text { index, full quality adjustment } \\
\text { Superlative (Fisher) volume }\end{array}$ & B & 2.25 & 2.04 & 2.44 & 4.86 & 4.95 & 2.22 \\
\hline index, full quality adjustment ${ }^{4}$ & $\mathrm{C}$ & 2.18 & 2.03 & 2.21 & 4.71 & 4.99 & 2.13 \\
\hline $\begin{array}{l}\text { Quality-adjustment effect under } \\
\text { fixed weights } \\
\text { Index number effect }\end{array}$ & $\begin{array}{l}B-A \\
C-B\end{array}$ & $\begin{array}{r}0.11 \\
-0.07\end{array}$ & $\begin{array}{r}0.00 \\
-0.01\end{array}$ & $\begin{array}{r}0.91 \\
-0.23\end{array}$ & $\begin{array}{r}0.58 \\
-0.15\end{array}$ & $\begin{array}{l}0.67 \\
0.03\end{array}$ & $\begin{array}{r}0.21 \\
-0.08\end{array}$ \\
\hline Total effect $^{5}$ & C-A & 0.04 & -0.01 & 0.68 & 0.43 & 0.71 & 0.13 \\
\hline \multicolumn{8}{|l|}{ Japan, 1985-94 - based on: } \\
\hline $\begin{array}{l}\text { Fixed-weight (Laspeyres) volume } \\
\text { index, original data }\end{array}$ & & 3.26 & 2.46 & 4.73 & 1.82 & 6.78 & 2.94 \\
\hline $\begin{array}{l}\text { Fixed-weight (Laspeyres) volume } \\
\text { index, no quality adjustment }{ }^{2} \\
\text { Fixed-weight (Laspeyres) volume }\end{array}$ & A & 3.26 & 2.46 & 4.73 & 1.82 & 6.78 & 2.94 \\
\hline index, full quality adjustment ${ }^{3}$ & B & 3.40 & 2.46 & 6.05 & 4.43 & 7.66 & 3.67 \\
\hline $\begin{array}{l}\text { Superlative (Fisher) volume } \\
\text { index, full quality adjustment }\end{array}$ & $\mathrm{C}$ & 3.27 & 3.59 & 5.16 & 2.84 & 7.25 & 3.41 \\
\hline $\begin{array}{l}\text { Quality-adjustment effect under } \\
\text { fixed weights }{ }^{5} \\
\text { Index number effect }\end{array}$ & $\begin{array}{l}B-A \\
C-B\end{array}$ & $\begin{array}{r}0.13 \\
-0.13\end{array}$ & $\begin{array}{l}0.00 \\
1.13\end{array}$ & $\begin{array}{r}1.32 \\
-0.88\end{array}$ & $\begin{array}{r}2.61 \\
-1.60\end{array}$ & $\begin{array}{r}0.88 \\
-0.41\end{array}$ & $\begin{array}{r}0.73 \\
-0.26\end{array}$ \\
\hline Total effect $^{5}$ & C-A & 0.01 & 1.13 & 0.44 & 1.01 & 0.47 & 0.47 \\
\hline \multicolumn{8}{|l|}{ Netherlands, $1986-93$ - based on: } \\
\hline $\begin{array}{l}\text { Fixed-weight (Laspeyres) volume } \\
\text { index, original data } 1\end{array}$ & & 3.06 & 1.98 & 1.57 & 4.91 & 4.17 & 3.16 \\
\hline $\begin{array}{l}\text { Fixed-weight (Laspeyres) volume } \\
\text { index, no quality adjustment }{ }^{2} \\
\text { Fixed-weight (Laspeyres) volume }\end{array}$ & A & 3.06 & 1.98 & 1.57 & 4.91 & 4.17 & 3.16 \\
\hline $\begin{array}{l}\text { index, full quality adjustment } \\
\text { Superlative (Fisher) volume }\end{array}$ & B & 3.18 & 1.98 & 2.93 & 5.87 & 5.49 & 3.42 \\
\hline index, full quality adjustment ${ }^{4}$ & C & 2.88 & 1.97 & 2.28 & 5.46 & 4.84 & 3.11 \\
\hline $\begin{array}{l}\text { Quality-adjustment effect under } \\
\text { fixed weights } 5\end{array}$ & $B-A$ & 0.12 & 0.00 & 1.36 & 0.96 & 1.31 & 0.27 \\
\hline Index number effect ${ }^{5}$ & C-B & -0.31 & -0.01 & -0.65 & -0.41 & -0.65 & -0.31 \\
\hline Total effect ${ }^{5}$ & C-A & -0.18 & -0.01 & 0.71 & 0.56 & 0.67 & -0.05 \\
\hline
\end{tabular}




\begin{tabular}{|c|c|c|c|c|c|c|c|}
\hline & & $\begin{array}{c}\text { Private } \\
\text { consumption } \\
\text { expenditure }\end{array}$ & $\begin{array}{l}\text { Government } \\
\text { expenditure }\end{array}$ & Investment & Exports & Imports & $\begin{array}{l}\text { Total final } \\
\text { expenditure }\end{array}$ \\
\hline \multicolumn{8}{|c|}{ United States, 1987-93 - based on: } \\
\hline $\begin{array}{l}\text { Fixed-weight (Laspeyres) volume } \\
\text { index, original data }\end{array}$ & A & 2.08 & 0.89 & 1.78 & 8.12 & 4.19 & 2.12 \\
\hline $\begin{array}{l}\text { Fixed-weight (Laspeyres) volume } \\
\text { index, no quality adjustment }{ }^{2} \\
\text { Fixed-weight (Laspeyres) volume }\end{array}$ & B & 2.05 & 0.85 & 0.82 & 7.49 & 3.26 & 1.99 \\
\hline $\begin{array}{l}\text { index, full quality adjustment } \\
\text { Superlative (Fisher) volume }\end{array}$ & C & 2.15 & 1.03 & 2.38 & 8.46 & 4.55 & 2.28 \\
\hline index, full quality adjustment ${ }^{4}$ & $\mathrm{D}$ & 2.08 & 0.99 & 1.73 & 8.01 & 3.99 & 2.13 \\
\hline $\begin{array}{l}\text { Quality-adjustment effect under } \\
\text { fixed weights }\end{array}$ & C-B & 0.10 & 0.19 & 1.56 & 0.97 & 1.29 & 0.29 \\
\hline Index number effect ${ }^{5}$ & D-C & -0.08 & -0.04 & -0.65 & -0.45 & -0.56 & -0.15 \\
\hline Total effect $^{5}$ & D-B & 0.03 & 0.15 & 0.91 & 0.53 & 0.73 & 0.14 \\
\hline
\end{tabular}

1. Volume growth rate of final expenditure components, based on aggregation across products with a Laspeyres-type index with fixed weights from the initial year. These data were either directly available from national input-output tables, or specifically calculated, e.g. for the Netherlands, whose input-output tables are based on quantity indices with annually adjusted weights (see Table 6).

2. Volume growth rate of final expenditure component, based on aggregation across products with a Laspeyres-type index with fixed weights from the initial year. In addition, where countries carry out full (hedonic) quality adjustment for certain products, these adjustments were removed. Where no adjustments are made in countries, this line is identical with line $A$.

3. Volume growth rate of final expenditure component, based on aggregation across products with a Laspeyres-type index with fixed weights from the initial year. In contrast to line B, a full quality adjustment was simulated for all relevant ICT products (see Table 7).

4. Volume growth rate of final expenditure component, based on aggregation across products with a Fisher-type index that averages weights from the initial and the final year. As in line C, full quality adjustment was simulated for all relevant ICT products.

5. A positive sign indicates that volume growth of the expenditure component has been understated, a negative sign indicates overstatement.

Source: OECD, based on national input-output tables. 
Table 6. Country-specific notes on the use of input-output tables

\begin{tabular}{|c|c|c|}
\hline Country & Size and years & Remarks \\
\hline Canada & $\begin{array}{l}485 \text { products, } 1992 \text { and } \\
1986 ; \text { price base } 1986\end{array}$ & $\begin{array}{l}\text { Final demand government consumption expenditure includes labour income } \\
\text { and depreciation relating to hospitals, education, defence. }\end{array}$ \\
\hline France & $\begin{array}{l}95 \text { products, } 1996 \text { and } \\
1985 ; \text { price base } 1980\end{array}$ & $\begin{array}{l}\text { Final demand government consumption expenditure does not include sales } \\
\text { to hospitals, education, defence, etc. These activities are part of industry and } \\
\text { deliveries show up as intermediate products. }\end{array}$ \\
\hline Japan & $\begin{array}{l}107 \text { products, } 1994 \text { and } \\
\text { 1985; price base } 1990\end{array}$ & $\begin{array}{l}\text { Final demand government consumption expenditure does not include sales } \\
\text { to hospitals, education, defence, etc. These activities are part of industry and } \\
\text { deliveries show up as intermediate products. As a consequence, there is no } \\
\text { direct government consumption of ICT products. }\end{array}$ \\
\hline Netherlands & $\begin{array}{l}628 \text { products, } 1993 \text { and } \\
1986 ; \text { annually adjusted } \\
\text { price base }\end{array}$ & $\begin{array}{l}\text { To isolate the "quality-adjustment" effect (based on fixed-weight indices) in } \\
\text { line with other countries, the annual (chained) price changes for each } \\
\text { product and demand component were converted into one price change for } \\
\text { the entire period. This provides an approximation to a fixed-weight } \\
\text { Laspeyres quantity index. At the time of calculation, import price indices } \\
\text { were available to the Secretariat only for the latest year (1992/93). For each } \\
\text { product, they were approximated as a geometric average of the price indices } \\
\text { of final demand components, adjusted by the observed ratio between import } \\
\text { and final demand price changes in } 1992 / 93 \text {. }\end{array}$ \\
\hline United States & $\begin{array}{l}182 \text { products, } 1993 \text { and } \\
1987 ; \text { price base } 1987\end{array}$ & $\begin{array}{l}\text { Final demand government consumption expenditure includes all sales to } \\
\text { hospitals, education, defence, etc. Unlike the Canadian input-output table, } \\
\text { labour income and other value-added components from these activities are } \\
\text { entered under an (otherwise empty) industry column for government } \\
\text { services. }\end{array}$ \\
\hline
\end{tabular}


Table 7. Information and communication technology products

\begin{tabular}{|c|c|c|c|c|}
\hline \multirow[t]{2}{*}{ Country } & \multirow[t]{2}{*}{ Product } & Price change ${ }^{1}$ & $\begin{array}{l}\text { Real price } \\
\text { change }^{2}\end{array}$ & $\begin{array}{l}\text { Unadjusted price } \\
\text { change minus } \\
\text { quality-adjusted } \\
\text { price change }^{3}\end{array}$ \\
\hline & & \multicolumn{3}{|c|}{ Average percentage change at annual rate } \\
\hline \multirow{8}{*}{$\begin{array}{l}\text { Canada, } \\
1986-92\end{array}$} & Computers, office machinery, excl. photo and fax & -11.9 & -15.3 & 10.0 \\
\hline & Radio, TV, stereo, VCR and unrecorded tape & 2.3 & -1.0 & 2.0 \\
\hline & Telephone and related equipment & 0.6 & -2.7 & 2.0 \\
\hline & Broadcasting and radio communication equipment & 0.2 & -3.1 & 2.0 \\
\hline & Radar and radio navigation equipment & 2.0 & -1.3 & 2.0 \\
\hline & Electronic equipment components & -2.7 & -6.1 & 10.0 \\
\hline & Telephone and other telecommunications & -1.5 & -4.9 & 2.0 \\
\hline & Computer services & -3.6 & -7.0 & 2.0 \\
\hline \multirow{5}{*}{$\begin{array}{l}\text { France, } \\
1985-96\end{array}$} & Office machinery and computers & -8.7 & -11.4 & 10.0 \\
\hline & $\begin{array}{l}\text { Professional electronic equipment (incl. communication } \\
\text { equipment) }\end{array}$ & 0.6 & -2.1 & 5.0 \\
\hline & $\begin{array}{l}\text { Household electronic appliances (radio, TV sets, } \\
\text { recorders) }\end{array}$ & -3.7 & -6.3 & 2.0 \\
\hline & Scientific and precision instruments & 3.7 & 1.0 & 2.0 \\
\hline & Telecommunication and postal services & -2.0 & -4.6 & 2.0 \\
\hline \multirow{10}{*}{$\begin{array}{l}\text { Japan, } \\
1985-94\end{array}$} & Office machinery, exc. computers & 0.8 & -0.7 & 2.0 \\
\hline & Household electric equipment & 0.7 & -0.8 & 2.0 \\
\hline & Electric computing equipment and accessory devices & -7.0 & -8.5 & 10.0 \\
\hline & Communication equipment & -9.5 & -11.0 & 2.0 \\
\hline & Applied electronic equipment & -14.1 & -15.6 & 2.0 \\
\hline & Electric measuring instruments & 1.6 & 0.1 & 2.0 \\
\hline & Semi-conductor devices and integrated circuits & -5.6 & -7.1 & 10.0 \\
\hline & Electronic tubes & -1.0 & -2.5 & 2.0 \\
\hline & Precision instruments & -0.4 & -1.9 & 2.0 \\
\hline & Communication & -1.4 & -2.9 & 2.0 \\
\hline \multirow{16}{*}{$\begin{array}{l}\text { Netherlands, } \\
\text { 1986-93 }\end{array}$} & Photocopiers, computers, office machinery and parts & -4.4 & -5.7 & 10.0 \\
\hline & Weighting machinery & 1.2 & -0.1 & 2.0 \\
\hline & Transmitters, receivers and combinations & 0.7 & -0.5 & 2.0 \\
\hline & Electronic valves & -0.1 & -1.3 & 2.0 \\
\hline & Printed circuits: elements & -1.7 & -2.9 & 10.0 \\
\hline & Navigation instruments & 1.1 & -0.1 & 2.0 \\
\hline & Medical equipment & 1.3 & 0.0 & 2.0 \\
\hline & $\begin{array}{l}\text { Instruments and appliances for measuring, checking } \\
\text { and testing }\end{array}$ & 1.2 & 0.0 & 2.0 \\
\hline & Telephones and telegraphs & -1.4 & -2.6 & 2.0 \\
\hline & Radios & -4.3 & -5.6 & 2.0 \\
\hline & TV receivers & -1.9 & -3.1 & 2.0 \\
\hline & TV cameras & -3.0 & -4.3 & 2.0 \\
\hline & Videorecorders & -3.8 & -5.0 & 2.0 \\
\hline & Microphones & -0.7 & -2.0 & 2.0 \\
\hline & Communication services & 2.2 & 0.9 & 2.0 \\
\hline & Computer services & -1.9 & -3.2 & 2.0 \\
\hline \multirow{7}{*}{$\begin{array}{l}\text { United States, } \\
1987-93\end{array}$} & Computer and office equipment & -16.8 & -20.4 & 10.0 \\
\hline & Household audio and video equipment & -4.8 & -8.4 & 2.0 \\
\hline & Communications equipment & 1.6 & -1.9 & 10.0 \\
\hline & Electronic components and accessories & -5.5 & -9.1 & 2.0 \\
\hline & Measuring and controlling devices & 3.3 & -0.2 & 2.0 \\
\hline & Communications & 1.5 & -2.1 & 2.0 \\
\hline & Computer and data processing services & 0.3 & -3.3 & 2.0 \\
\hline
\end{tabular}

1. Implicit deflator of final demand (excluding variations in stocks), based on input-output tables at producer prices.

2. Price change of ICT product minus price change of all products.

3. Assumed average annual percentage point difference between unadjusted and fully quality-adjusted deflators.

See Boxes 1 and 2 for a review of empirical studies and justification

Source: National input-output tables; OECD. 


\section{ANNEX 1. STATISTICAL METHODS OF ICT PRICE MEASUREMENT}

\section{Quality change and new goods}

The rapid development of information and communication technology products has brought centre-stage two long-standing questions of price measurement: how to deal with quality changes of existing goods and how to account for new goods in price indices. The distinction between these two issues is blurred because it is unclear where to draw the borderline between a "truly" new good and a new variety of an existing good. ${ }^{19}$

Economically, new varieties of existing goods as well as quality improvement of existing goods can in fact be considered as special cases of "new goods" if this notion is defined broadly enough: the emergence of new varieties of existing goods is a case of horizontal differentiation, quality improvement a case of vertical differentiation (where the product with inferior quality may or may not disappear) and the emergence of entirely new goods spans a new dimension in product space. The continuum from simple varieties of existing goods (such as producing the same car in an additional colour), over their quality improvement (such as supplying more powerful computers) to entirely new products (jet planes, personal computers) can also be associated with a declining elasticity of substitution between the new products and existing ones: there is much greater substitutability between a new variety of an existing good and the other varieties of the same good than between a totally new good that holds some form of monopoly position. From a viewpoint of economic theory, the welfare effects arising to consumers and/or producers from the introduction of new goods, should be reflected in price and quantity measures if the latter are to provide an approximation to the measurement of living standards or utility.

\section{Methods}

Typically, statistical agencies derive price indices for products by observing price changes of items in a representative sample. New products, quality change and new variants are common phenomena in the observation of price changes of items, and statistical offices have well-established procedures to deal with them: ${ }^{20}$

- Quality adjustment through model substitution: a frequent occurrence is the need for substitution of particular items that are replaced by new models. The new model or variety is compared to the old one ${ }^{21}$ and a judgement is made to what extent any price difference between the two should be considered a change in quality or a change in prices. However, if quality improvements are larger than the observed price difference, quality changes will be undervalued and price changes overstated. This can only be avoided through the explicit imputation of a quality-adjusted price (derived, for instance, from hedonic methods) for the replacement item. Restricting the sample to models that are identical between two periods can isolate pure price changes of these established models but fails to be representative for an entire product group if the established models' price changes fail to duplicate the price changes of new models - a situation that is frequently encountered in ICT markets.

19. For an overview of the issues involved, see Bresnahan and Gordon (1996).

20. For example, Lowe (1996) provides an overview of how quality change is handled in the Canadian National Accounts.

21. An extensive discussion about the practice of quality adjustment in the United States CPI can be found in Moulton and Moses (1997). 
- Genuinely new items within a product group are normally linked into the sample of observations some time after their occurrence on the market. However, in technologically dynamic industries, new products' prices often fall very rapidly and before they are linked into the sample. A price index will then not pick up the initial fall in prices. Immediate introduction of new items, on the other hand, poses the problem of reservation prices, i.e. the imputation of hypothetical prices for the new items in the preceding period (when they were still unavailable). One method to obtain such hypothetical prices, both for new goods and for exiting ones, is the hedonic method (see below). ${ }^{22}$

- A related problem is the judgement about the nature of new items: are they highly substitutable with existing ones or are they actually a new type of item within a product class? In the first case, they should be treated jointly with another item; in the second case, a separate sub-category should be opened for them. This choice can have sizeable influence on the resulting price index as was shown by Berndt et al. (1996) for the case of branded and generic pharmaceuticals.

Hedonic methods draw on the idea that "production or consumption of heterogeneous goods can be analysed by disaggregating them into more basic units that better measure the dimensions of what is bought and sold - the characteristics" (Triplett, 1986). A unit of a good is then defined as a combination of characteristics and, often, new and improved goods can simply be defined as modified combinations or bundles of characteristics. The hedonic method permits both the computation of reservation prices and their use in linking different models. Alternatively, hedonic regression models can be used to directly infer price changes of a product group. ${ }^{23}$ Because they have been extensively applied for price measurement of computers, their advantages and potential drawbacks are discussed in greater detail below.

Methods based on the econometric estimation of entire demand systems aim at assessing welfare effects from entirely new goods, quality improvement and increased variety. Such econometric models are attractive in the sense that they are directly in line with economic theory and permit the treatment of more complex relationships between different goods or between existing and new goods. At the same time, they are computationally demanding, and often sensitive to particular specifications and assumptions. As such, they cannot provide a practicable alternative to traditional methods of price measurement. ${ }^{24}$

\section{Hedonic methods for computers: a brief discussion}

As outlined earlier, the hedonic approach is one of the tools for quality adjustment. Essentially, it redefines goods in terms of their characteristics so that modified or new models do not open up a new product category but simply represent a new combination of characteristics. Thus, to some extent, the shift to characteristics does away with the question of how to deal with new goods; at least as long as new goods do not incorporate fundamentally new characteristics. In the case of computers, where hedonics have been widely used, the typical characteristics are specifications such as speed, memory size and so forth. Empirically, a hedonic function is estimated, relating observations of prices of computer "boxes" to their respective characteristics. One of the uses of the hedonic function is to estimate reservation prices of new models - given their characteristics, an evaluation can be made of how much such a new model would have cost in a previous period. Alternatively, price changes can be obtained directly from hedonic regressions,

22. Matched-models combined with results from hedonic regressions to form reservation prices is the method currently followed by the United States Bureau of Economic Analysis for their (mainframe) computer and peripheral equipment price indices.

23. See, for instance, Berndt and Griliches (1993) for an application to personal computers

24. Examples for studies in the area of ICT are Greenstein (1996); Oi (1996); Trajtenberg (1990). 
using dummy variables for individual years. As the overview in Box 1 shows, price indices for computers, based on hedonic techniques, tend to exhibit rapid declines.

Two assumptions underlying hedonic methods should be noted: $i$ ) the behavioural assumption of the hedonic hypothesis is that computer characteristics are true inputs to the production process, in the case of firms, or true arguments to household production or utility, in the case of consumers; ii) following economic theory (Fisher and Shell, 1972), consumer price indices or input price indices (in the case of firms) should measure changes in total expenditure between two periods, given a constant level of utility (for consumers) or output (for firms) and changing prices of consumption goods (factor inputs). A full input price index would thus evaluate the price changes of computer characteristics simultaneously with the price changes of other inputs to a production process. Empirically, this is impractical and an assumption is made to separate the characteristics price index from other inputs. A hedonic price index is then considered an approximation to this true characteristics price index. Note that the assumptions underlying the construction of hedonic output price indices are less stringent.

Despite apparent interesting features, the uptake of hedonic methods as a tool in the pricing of high-technology goods has been confined to a small number of countries and products. Reasons for caution include:

- The hedonic hypotheses, stating that computer characteristics are the true and separable arguments in utility and production functions, may lead to an overestimation of the utility gains associated with increased power of hardware. McCarthy (1997) questions whether hedonic functions take all essential characteristics into account, arguing that computers should be seen as systems where hardware and software characteristics cannot be separated. McCarthy points out that, if the slower price decline of software was taken into account, the overall price changes of computer systems would be less dramatic than those based on hardware characteristics only. Also, the problem of factoring in training costs and the degree of actual use is unresolved, although, in principle, it should be reflected in an input price index. This may be more important for consumers than for firms and hence more important for deflation of private consumption than for investment.

- A second point is that if only computer prices are hedonically adjusted, productivity gains and real value-added growth of the computer industry will be overestimated because other high-tech products that are used as inputs are not hedonically adjusted. While this is a valid criticism, it points to the necessity of applying the hedonic adjustment procedure to a broader range of products.

- Similarly, individual hedonically adjusted price indices may overestimate volume growth of aggregate output if used within fixed-weight quantity indices. Again this makes more a cause for using superlative index numbers than for abolishing hedonic adjustments. On practical grounds, statistical offices often find true superlative index numbers inconvenient (they may compromise timeliness of statistics or cause revisions). As a compromise, a recent report by the European Commission recommends that annually chained Laspeyres indices be used for practical purposes; these avoid many of the disadvantages of Laspeyres indices with a fixed base year and are less costly to implement than Fisher indices.

- Finally, the construction of hedonic deflators tends to be costly for statistical offices because a sizeable amount of primary data must be gathered, evaluated by specialists and treated in a comparatively resource-demanding econometric methodology. This involves fixed costs that weigh more heavily in the statistics budget of small countries than larger ones. 


\section{ANNEX 2. EFFECTS ON MEASURED FINAL EXPENDITURE: METHODOLOGY}

This annex describes the methodology to evaluate the effects of introducing full quality adjustment of ICT goods prices on final expenditure components and aggregate GDP, based on current and constant price input-output tables of the United States, Canada, the Netherlands, France and Japan (valuation at producer prices).

\section{Quality adjustment effect}

For each product $i=1,2, \ldots N$ and each final expenditure component $F D=C, I, G, X, M$ (private consumption, gross fixed capital formation, government consumption expenditure, exports and imports), the implicit product price index between $t_{0}$ and $t_{1}, P_{i, t 1} F D$ was calculated as the ratio between current and constant price expenditure. The final demand component "changes in stocks" was ignored to avoid problems of aggregation (mixing positive and negative weights). Given its comparatively small size, the omission generates only a minimum bias.

Next, for each country, $M$ different ICT products $k=1,2, \ldots M$ were identified (Table 7). Because national input-output tables were used, the number of ICT products varies between the five countries. This introduces an aggregation bias and care must be taken in the interpretation of cross-country comparisons of results. Each ICT product was assigned an unadjusted and an adjusted price index, $p_{k, t 1}{ }^{F D}$ and $\tilde{p}_{k, t 1}{ }^{F D}$. As outlined above, the adjusted price index reflects quality improvements and differs from the unadjusted price index in that its compound rates of change falls by $\lambda_{k}$ percentage points less per year: ${ }^{25} \Delta \ln \left(p_{k}^{F D}\right) /(t 1-t 0)-\Delta \ln \left(\tilde{p}_{k}^{F D}\right) /(t 1-t 0)=\lambda_{k}$.

Depending on the country and on the product, the original price index from the input-output table was identified either with the adjusted or unadjusted price index. For example, the United States use a hedonically adjusted price index for their product group "computers". In this case, the unadjusted price index $p_{k, t 1}{ }^{F D}$ was calculated and $\tilde{p}_{k, t 1}{ }^{F D}$ was identified with the original price index. Corresponding to each price index is a volume measure: $q_{k, t 1} F D=\frac{p_{k, t 1}{ }^{F D} q_{k, t 1} F D}{p_{k, t 1} F D}$ and $\tilde{q}_{k, t 1} F D=\frac{p_{k, t 1} F D q_{k, t 1} F D}{\tilde{p}_{k, t 1} F D}$.

$$
\begin{aligned}
& \text { 25. Because } p_{k, t 1} F D \text { is a price index with } p_{k, t 0} F D=1 \text {, its compound rate of change is simply } \\
& \Delta \ln \left(p_{k}^{F D}\right)=\ln \left(p_{k, t 1} F D\right)-\ln \left(p_{k, t 0} F D\right) \text {. The same holds for } \tilde{p}_{k, t 1} F D \text {. }
\end{aligned}
$$


The two sets of prices gave rise to two sets of final demand aggregates, $V L_{t 1} F D$ (unadjusted) and $V \tilde{L}_{t 1}{ }^{F D}$ (adjusted), each calculated as a quantity Laspeyres index:

$V L_{t 1} F D=\frac{\sum_{i \neq k} p_{i, t 0}^{F D} q_{i, t 1} F D+\sum_{i=k} p_{i, t 0}^{F D} q_{i, t 1} F D}{\sum_{i} p_{i, t 0}^{F D} q_{i, t 0} F D}$

and

$V \tilde{L}_{t 1}^{F D}=\frac{\sum_{i \neq k} p_{i, t 0}^{F D} q_{i, t 1}{ }^{F D}+\sum_{i=k} \tilde{p}_{i, t 0}^{F D} \tilde{q}_{i, t 1} F D}{\sum_{i} p_{i, t 0}^{F D} q_{i, t 0} F D}$

The quality-adjustment effect for demand component FD was then calculated as $V \tilde{L}_{t 1} F D / V L_{t 1} F D$. Because $p_{k}^{F D}>\tilde{p}_{k}^{F D}$, the quality adjustment effect is always positive (i.e. $V \tilde{L}_{t 1} F D / V L_{t 1} F D>1$ ).

\section{Index number effect}

For the calculation of the index number effect, quality-adjusted Paasche volume indices $V \tilde{P}_{t 1} F D$ were introduced for each demand component:

$$
V \tilde{P}_{t 1}^{F D}=\frac{\sum_{i \neq k} p_{i, t 1}^{F D} q_{i, t 1}^{F D}+\sum_{i=k} \tilde{p}_{i, t 1}^{F D} \tilde{q}_{i, t 1} F D}{\sum_{i \neq k} p_{i, t 1}^{F D} q_{i, t 0}^{F D}+\sum_{i=k} \tilde{p}_{i, t 1}^{F D} q_{i, t 0} F D} .
$$

The corresponding Fisher indices are given by $V \tilde{F}_{t 1} F D=\left(V \tilde{L}_{t 1} F D \cdot V \tilde{P}_{t 1} F D\right)^{0.5}$ and the index number effect, i.e. the effect of replacing a fixed-weight Laspeyres volume index by a superlative Fisher volume index is $V \tilde{F}_{t 1} F D / V \tilde{L}_{t 1} F D$.

\section{Aggregation across final expenditure components}

The final calculation concerned the effects on total expenditure, which provides a close approximation to GDP. The unadjusted and adjusted Laspeyres quantity indices for total expenditure were 
evaluated as the average of quantity indices of the demand components with weights $s_{t 0} F D$, the current price shares of final expenditure component FD in the base year $t_{0}$ :

$$
V L_{t 1}=\sum_{F D=C, G, I, X} s_{t 0}^{F D} \cdot V L_{t 1} F D-s_{t 0}{ }^{M} \cdot V L_{t 1}{ }^{M}
$$

and

$$
V \tilde{L}_{t 1}=\sum_{F D=C, G, I, X}{ }_{s}{ }^{F D} \cdot V \tilde{L}_{t 1}{ }^{F D}-s_{t 0}{ }^{M} \cdot V \tilde{L}_{t 1}{ }^{M}
$$

with

$$
s_{t 0}^{F D}=\frac{\sum_{i} p_{i, t 0}^{F D} \cdot q_{i, t 0} F D}{\sum_{F D=C, G, I, X}\left(\sum_{i} p_{i, t 0}^{F D} \cdot q_{i, t 0}^{F D}\right)-\sum_{i} p_{i, t 0}^{M} \cdot q_{i, t 0}^{M}} .
$$

Similarly, a quality-adjusted Paasche quantity index was constructed as a weighted average of the Paasche indices of the five final expenditure components, with weights $\tilde{s}^{F D}$, each final expenditure component's share in base-year quantities, evaluated at prices of $t_{1}$ :

$$
V \tilde{P}_{t 1}=\sum_{F D=C, G, I, X} \tilde{s}^{F D} \cdot V \tilde{P}_{t 1}^{F D}-\tilde{s}^{M} \cdot V \tilde{P}_{t 1}{ }^{M}
$$

with

$$
\tilde{s}^{F D}=\frac{\sum_{i} \tilde{p}_{i, t 1}^{F D} \cdot q_{i, t 0} F D}{\sum_{F D=C, G, I, X}\left(\sum_{i} \tilde{p}_{i, t 1}^{F D} \cdot q_{i, t 0} F D\right)-\sum_{i} \tilde{p}_{i, t 1}^{M} \cdot q_{i, t 0} M} .
$$

The final step involved the computation of a quality-adjusted and an unadjusted Fisher index, $V F_{t 1}=\left(V L_{t 1} \cdot V P_{t 1}\right)^{0.5}$, and $V \tilde{F}_{t 1}=\left(V \tilde{L}_{t 1} \cdot V \tilde{P}_{t 1}\right)^{0.5}$ to distinguish the quality-adjustment effect for total final expenditure, $V \tilde{L}_{t 1} / V L_{t 1}$ and the index number effect $V \tilde{F}_{t 1} / V \tilde{L}_{t 1}$. 


\section{REFERENCES}

BAILY, Martin N. and Robert J. GORDON (1988), “The Productivity Slowdown, Measurement Issues, and the Explosion of Computer Power", Brookings Papers on Economic Activity.

BALDWIN, Andrew, Pierre DESPRÉS, Alice NAKAMURA and Masao NAKAMURA (1997), "New Goods from the Perspective of Price Index Making in Canada and Japan", in Bresnahan and Gordon (eds.).

BAUMOL, William J., Sue Anne BATEY BLACKMAN and Edward N. WOLFF (1992), Productivity and American Leadership: The Long-run View, MIT Press.

BERNDT, Ernst and Zvi GRILICHES (1993), "Price Indexes for Microcomputers: An Exploratory Study”, in Foss et al. (eds.) (1993).

BERNDT, Ernst, Zvi GRILICHES and Neal J. RAPPAPORT (1995), "Econometric Estimates of Price Indexes for Personal Computers in the 1990s", Journal of Econometrics 68.

BERNDT, Ernst R., Iain M. COCKBURN and Zvi GRILICHES (1996), "Pharmaceutical Innovations and Market Dynamics: Tracking Effects on Price Indexes for Antidepressant Drugs', Brookings Papers on Economic Activity: Microeconomics.

BERNSTEIN, Jeffrey I. (1997), "Total Factor Productivity Growth in the Canadian Life Insurance Industry: 1979-1989", paper presented at the 1997 CSLS Conference on Service Sector Productivity and the Productivity Paradox.

BOSKIN, Michael, Ellen R. DULBERGER, Robert J. GORDON, Zvi GRILICHES, Dale JORGENSON (1996), "Towards a More Accurate Measure of the Cost of Living", Report to the United States Senate Finance Committee by the Advisory Commission to Study The Consumer Price Index.

BRESNAHAN, Timothy F. and Robert J. GORDON (eds.) (1996), The Economics of New Goods, Studies in Income and Wealth, University of Chicago Press.

COLE, Rosanne, Y.C. CHEN, Joan A. BARQUIN-STOLLEMAN, Ellen DULBERGER, Nurhan HELVACIAN and James H. HODGE (1986), "Quality-Adjusted Price Indexes for Computer Processors and Selected Peripheral Equipment", Survey of Current Business 66.

DENECKERE, Raymond J. and R. Preston McAFEE (1996), "Damaged Goods", Journal of Economics and Management Strategy 5 (2, Summer).

DENISON, Edward F. (1989), Estimates of Productivity Change by Industry: An Evaluation and an Alternative, The Brookings Institution.

DULBERGER, Ellen R. (1989), “The Application of a Hedonic Model to a Quality-Adjusted Price Index for Computer Processors”, in Jorgenson and Landau (eds.) (1989).

DULBERGER, Ellen R. (1993), "Source of Price Decline in Computer Processors: Selected Electronic Components", in Foss et al. (eds.) (1993).

FLEMING, Martin (1996), "The GDP Revisions and Understanding Sluggish Productivity Growth", Business Economics, April.

FISHER, Franklin M., and Karl SHELL (1972), The Economic Theory of Price Indices, New York.

FIXLER, Dennis and Kim ZIESCHANG (1997), "The Productivity of the Banking Sector: Integrating Financial and Production Approaches to Measuring Financial Service Output", paper presented at the 1997 CSLS Conference on Service Sector Productivity and the Productivity Paradox. 
FLAMM, Kenneth (1987), Targeting the Computer, Washington, DC, The Brookings Institution.

FOSS, Murray F., Marilyn E. MANSER and Allan H. YOUNG (eds.) (1993), Price Measurement and their Uses, University of Chicago Press.

GANDAL, Neil (1994), "Hedonic Price Indexes for Spreadsheets and an Empirical Test for Network Externalities", Rand Journal of Economics, Vol. 25.

GORDON, Robert J. (1989), “The Post-war Evolution of Computer Prices”, in Jorgenson and Landau (eds.) (1989).

GORDON, Robert J. (1990), The Measurement of Durable Goods Prices, University of Chicago Press.

GORDON, Robert J. (1991), "Measurement Issues and the Productivity Slowdown in Five Major Industrial Countries", in OECD (1991), Technology and Productivity: The Challenge for Economic Policy, Paris.

GREENSTEIN, Shane M. (1996), "From Superminis to Supercomputers: Estimating Surplus in the Computing Market", in Bresnahan and Gordon (1996).

GRILICHES, Zvi (1994), "Productivity, R\&D and the Data Constraint", American Economic Review, 80.

GORDON, Robert J. (1989), “The Post-war Evolution of Computer Prices”, in Jorgenson and Landau (eds.).

GRIMM, B. (1995), "Quality-adjusted price Indices for some metal oxide semiconductor integrated circuits", unpublished paper, Bureau of Economic Analysis, quoted from Triplett (1996).

HARHOFF, Dietmar and Dietmar MOCH (1996), Price Indexes for PC Database Software and the Value of Code Compatibility, ZEW Discussion Paper No 96-17, Mannheim.

HULTEN, Charles (1992), "Growth Accounting When Technical Change Is Embodied in Capital"; American Economic Review, Vol. 82.

JORGENSON, Dale W. and Ralph LANDAU (eds.) (1989), Technology and Capital Formation, MIT Press.

LANDEFELD, Steven J. and Robert P. PARKER (1995), "Preview of the Comprehensive Revision of the National Income and Product Accounts: BEA's New Featured Measures of Output and Prices", Survey of Current Business, July.

LICHT, Georg and Dietmar MOCH (1997), "Innovation and Information Technology in Services", paper presented at the 1997 CSLS Conference on Service Sector Productivity and the Productivity Paradox.

LOWE, Robin (1996), "Handling Quality Changes in the Canadian National Accounts Price Deflators", in OECD (1996).

McCARTHY, Paul (1997), "Computer Prices: How Good is the Quality Adjustment?", paper presented at the OECD Capital Stock Conference, Canberra.

MILLER, Nugent (1994), "Deflation of Computers in the Canadian Input-Output Accounts", paper presented at the 23rd General Conference of the International Association for Research in Income and Wealth.

MOULTON, Brent R. and Karin E. MOSES (1997), "Addressing the Quality Change Issue in the Consumer Price Index”, Brookings Papers on Economic Activity 1.

NORSWORTHY, John R. and Show-Ling JANG (1993), "Cost Function Estimation of Quality Change in Semiconductors", in Foss et al. (eds.) (1993).

OECD (1996), Industry Productivity: International Comparison and Measurement Issues, OECD Proceedings. 
OECD (1997a), Information Technology Outlook 1997, Paris.

OECD (1997b), Science, Technology and Industry: Scoreboard of Indicators 1997, Paris.

OECD (1998), Science, Technology and Industry Outlook, Paris.

OI, Walter Y. (1996), “The Welfare Implications of Invention”, in Bresnahan and Gordon (1996).

OLINER, Stephen D. (1993), "Constant-Quality Price Change, Depreciation, and Retirement of Mainframe Computers", in Foss et al. (eds.) (1993).

OLINER, Stephen D. and Daniel E. SICHEL (1994), "Computers and Output Growth Revisited: How Big Is the Puzzle?", Brookings Papers on Economic Activity 2.

ROOS, Pontus (1997), "Measurement of Productivity in Hospital Services Using Malmquist Index Approaches: A Discussion of Methods and Illustration to Eye Surgery", paper presented at the 1997 CSLS Conference on Service Sector Productivity and the Productivity Paradox.

SADÉE, N. (1996), "Computer Prices in the National Accounts: An Update from the Comprehensive Revision”, US Bureau of Economic Analysis, quoted after Triplett (1996).

SHIRATSUKA, Shigenori (1995), "Effects of Quality Changes on the Price Index: A Hedonic Approach to the Estimation of a Quality Adjusted Price Index for Personal Computers in Japan”, Bank of Japan Monetary and Economic Studies, Vol. 13.

SICHEL, Daniel E. (1994); “The Computer Paradox and the Productivity Slowdown: Is Mismeasurement the Culprit?", unpublished paper, The Brookings Institution.

STIROH, Kevin J. (1997), “Computers, Productivity and Input Substitution”, unpublished paper.

TRAJTENBERG, M. (1990), Economic Analysis of Product Innovation - The Case of CT Scanners, Harvard University Press.

TRIPLETT, Jack (1986), “The Economic Interpretation of Hedonic Methods”, Survey of Current Business, January.

TRIPLETT, Jack (1989), "Price and Technological Change in a Capital Good", in Jorgenson and Landau (eds.) (1989).

TRIPLETT, Jack (1990), "Hedonic Methods in Statistical Agency Environments: An Intellectual Biopsy", in Ernst R. Berndt and Jack E. Triplett (eds.), Fifty Years of Economic Measurement, NBER Studies in Income and Wealth Volume 54.

TRIPLETT, Jack (1992), "Economic Theory and BEA's Alternative Quantity and Price Indexes", Survey of Current Business, April.

TRIPLETT, Jack (1996), "High-tech Industry Productivity and Hedonic Price Indices”, in OECD (1996).

TRIPLETT, Jack (1996), "Depreciation in Production Analysis and in Income and Wealth Accounts: Resolution of an old Debate", Economic Inquiry, January.

WYCKOFF, Andrew W. (1995), "The Impact of Computer Prices on International Comparisons of Labour Productivity”, Economics of Innovation and New Technology, Vol. 3.

YOUNG, Allan H. (1992), "Alternative Measures of Change in Real Output and Prices", Survey of Current Business, April. 


\title{
STI WORKING PAPERS
}

\author{
1996
}

1. Embodied Technology Diffusion: An Empirical Analysis for 10 OECD Countries George Papaconstantinou, Norihisa Sakurai and Andrew Wyckoff

2. The Impact of R\&D and Technology Diffusion on Productivity Growth: Evidence for 10 OECD Countries in the 1970s and 1980s

Norihisa Sakurai, Evangelos Ioannidis and George Papaconstantinou

3. Short-term Indicators: Using Qualitative Indicators to Update Production Indices

Paul Schreyer and Corinne Emery

4. SMEs and Employment Creation: Overview of Selected Quantitative Studies in OECD Member Countries

Paul Schreyer

5. Globalisation and Competitiveness: Relevant Indicators

Thomas Hatzichronoglou

6. Factors Influencing the Steel Work Force: 1990 to 1995

Donald F. Barnett

7. Measuring R\&D in the Services

Alison Young

8. The Evolution of Skills in OECD Countries and the Role of Technology

A. Colecchia and G. Papaconstantinou

1997

1. Bibliometric Indicators and Analysis of Research Systems: Methods and Examples

(disponible en français sous le titre "Indicateurs bibliométriques et analyse des systèmes de recherche : méthodes et exemples")

Yoshiko Okubo

2. Revision of the High-technology Sector and Product Classification

(disponible en français sous le titre "Révision des classifications des secteurs et des produits de haute technologie")

Thomas Hatzichronoglou 
1. Relative Trade-weighted Unit Labour Costs by Industry

Karine Lepron and Paul Schreyer

2. Information and Communication Technology and the Measurement of Real Output, Final Demand and Productivity

Paul Schreyer

3. Institutional Arrangements for Access to Confidential Micro-level Data in OECD Countries Kazuyuki Motohashi 